\title{
As transformações no abastecimento de carne na cidade de São Paulo na última década imperial (1880-1887)
}

\author{
The transformations in the meat supply at the city of São Paulo in the last \\ decade of the imperial regime (1880-1887)
}

\section{Leopoldo Fernandes da Silva*}

\section{Resumo}

Este estudo de história da cidade de São Paulo aborda as transformações no abastecimento de carne na última década do regime imperial, no bojo dos processos de expansão e modernização urbanas desencadeados pela economia cafeeira. Por meio da pesquisa em atas da Câmara, jornais, abaixo-assinados e relatórios oficiais, reconstituiu-se a mobilização dos comerciantes de carne em defesa de seus interesses, no processo de transferência do matadouro da cidade, no ano de 1886. Desse modo, apreendemos a parțicipação desse segmento social na urbanização da Capital, assim como de que modo estes processos modificaram a sua rotina de trabalho e a organização do abastecimento de carnes na cidade, em um contexto de transformação do espaço urbano e de seus usos.

Palavras-chave: Abastecimento de alimentos; São Paulo (cidade); Carne; Saúde pública; Porco.

\begin{abstract}
This article addresses the history of the city of São Paulo studying the meat supply transformation under the imperial's regime last decade, 1880-1887, due to the urban space expansion and modernization in the context of the coffee economic growth. Through empirical research in chamber documents, newspapers, collective undersigned documents, and official reports, we analyze the meat merchants' political movement to influence the city's slaughterhouse transferring process, in the year of 1886. Thus, we could seize the influence of this social segment in the urbanization process as well as the ways it modified the meat merchant's labor routine and the organization of the meat supply at the city in a context of urban space and its uses transformation.
\end{abstract}

Keywords: Food supply; São Paulo (city); Meat; Public health; Pork.

* Pós-doutorando na Faculdade de Medicina da Universidade de São Paulo. Licenciado em Ciências Sociais pela UNICAMP. Mestre é doutor em História Econômica no departamento de História da FFLCH/USP. E-mail: lefer08silva@gmail.com 


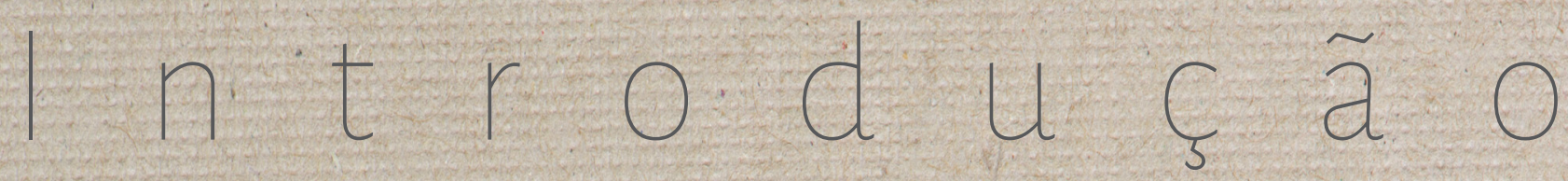

os estudos históricos brasileiros, o campo de pesquisas em história do abastecimento de gêneros alimentícios se consolidou na década de 1970, em um contexto de mudanças epistemológicas na ciência histórica, no qual as metodologias estruturalistas de análise foram criticadas à luz de novos aportes teórico-metodológicos, como a história social e a microanálise. Neste contexto, a delimitação do campo de pesquisas em história do abastecimento se caracterizou pelo deslocamento do objeto de análise da configuração da economia brasileira relacionada ao mercado externo para as dinâmicas do mercado interno e seus desdobramentos sociopolíticos, até então negligenciados no estudo da formação socioeconômica brasileira em trabalhos clássicos, como os de Simonsen (2005) e Furtado (2014).

O estudo do mercado interno redimensionou imagens cristalizadas por estes autores, especialmente no que se refere à tese da decadência econômica, no período de passagem da Colônia para o Império, entre a segunda metade do século XVIII e as primeiras décadas do XIX. Esta tese se baseia em uma perspectiva de dinâmica econômica brasileira vinculada à existência de uma produção de mercadorias voltada para o comércio internacional - como nos casos dos ciclos do açúcar, ouro, café-, minimizando o papel de outras esferas produtivas nesse processo, como a organização da economia de abastecimento de gêneros alimentícios.

Em trabalhos como os de Lenharo (1979) e Petrone (1976), a pesquisa histórica sobre a constituição desse mercado interno demonstrou que a produção e o comércio de alimentos e animais desempenharam papel relevante na acumulação mercantil em regiões como São Paulo, Rio de Janeiro e Minas Gerais, desde o período colonial, favorecendo o deslocamento do eixo econômico das regiões norte e nordeste para o centro sul do território. A ascensão social de grupos ligados à economia de abastecimento se traduziu na participação política em processos históricos como a urbanização das cidades brasileiras no século XIX, bem como na Independência do Brasil e na subsequente organização do Estado nacional.

Neste artigo, propomos investigar o abastecimento de gêneros alimentícios sob o prisma das relações estabelecidas com os processos de urbanização e de participação política de grupos 
sociais vinculados à produção e ao comércio de alimentos. O local e contexto delimitados se situam na cidade de São Paulo, na última década do regime imperial, 1880-1890, período em que as transformações socioeconômicas suscitadas pela economia cafeeira impactaram de forma significativa a organização do espaço da cidade, em função dos processos de expansão e modernização urbanas.

No decorrer do século XIX, a economia de abastecimento que, tradicionalmente, constituía "palco de muita concorrência entre os atravessadores urbanos (mercadores, especuladores) e os setores mais pobres das cidades" se tornará objeto de maior controle "das autoridades fiscais e municipais, a vigilância dos almotacéis e a cobrança de licenças e multas" (DIAS, 1985, p. 92-93). Entretanto, segundo observa Glezer, as intenções normativas e reguladoras da Câmara Municipal raramente foram implementadas, "a administração municipal no Império não conseguira regulamentar e controlar a vida urbana, por carência de autoridade e de recursos financeiros, pela dependência legal e orçamentária da Assembleia Provincial" (GLEZER, 2007, p. 170).

Nesse contexto histórico e político, o estudo da intervenção do poder municipal na produção e comércio de carnes em São Paulo - por meio da organização de instituições públicas e da mobilização política dos comerciantes desse

A importância adquirida pelo abastecimento de alimentos, na agenda política e fiscal da municipalidade, como uma dimensão fundamental para o exercício do poder local sobre o espaço urbano e para a execução dos planos de modernização da cidade, nas décadas finais do Império. gênero alimentício - aponta para a importância adquirida pelo abastecimento de alimentos, na agenda política e fiscal da municipalidade, como uma dimensão fundamental para o exercício do poder local sobre o espaço urbano e para a execução dos planos de modernização da cidade, nas décadas finais do Império.

Em 1867, na cidade de São Paulo, inaugura-se o primeiro mercado municipal, denominado Praça do Mercado da Rua 25 de Março. Este estabelecimento públicosimbolizou a ampliação do poder municipal sobre o comércio de alimentos, pois o regulamento do mercado normatizava práticas e condutas desejáveis nos negócios do abastecimento, visava também aprimorar o controle fiscal e sanitário sobre esse segmento da economia, bem como monitorar a circulação de grupos sociais - como caipiras, quitandeiras e comerciantes de secos e molhados - em um espaço urbano em transformação, no qual as práticas e os hábitos destes grupos passavam a 
ser vistos como arcaicos e incompatíveis com os planos de modernização que as elites políticas visavam instaurar (SILVA, 2018).

Além da praça do mercado, o Matadouro Municipal também se constituiu em instrumento, de intervenção do poder local sobre a economia de abastecimento urbano. Neste outro estabelecimento público, a Câmara supervisionava a produção e o comércio de carne e outras mercadorias derivadas da produção de animais de corte - chifres, couro, sangue -, as quais eram utilizadas como matéria-prima nas primeiras indústrias alimentícias, de calçados e nos curtumes da cidade. Em um contexto de formação de relações sociais de trabalho livre, o matadouro consistia em um espaço de produção fundamental para o desenvolvimento do processo de industrialização em São Paulo (SILVA, 2018).

No âmbito desta discussão, analisamos a participação política dos comerciantes de carne em São Paulo, conhecidos então como "marchantes", por meio de dois questionamentos: como este grupo social interagiu com os processos de expansão e modernização urbanas? De que modo os marchantes reagiram ao recrudescimento do controle e intervenção das autoridades municipais sobre a produção e o comércio de carnes?

Os marchantes constituíam um grupo profissional de comerciantes de animais de corte, carne e produtos derivados do abate de rezes. Compravam os animais nas regiões produtoras e os conduziam para as cidades, com o objetivo de abatê-los no matadouro, produzindo carne e outras mercadorias. Desse modo, negociavam uma gama variada de produtos obtidos nessa atividade, especialmente a carne e o couro. A existência deste grupo profissional remonta ao período colonial, segundo os relatos de memorialistas. Na passagem do século XIX para o XX, com o advento da tecnologia de refrigeração e dos matadouros frigoríficos, a organização do abastecimento urbano de carnes foi reconfigurada, surgindo grandes empresas vinculadas ao setor e eliminando-se progressivamente a profissão de marchante. $O$ objetivo deste estudo consiste em reconstituir os primórdios deste processo em São Paulo, analisando suas especificidades, bem como os meios de defesa deste grupo social para resistir a esse processo que acarretava na exclusão de sua profissão.

A participação social dos marchantes será investigada nos últimos anos do regime imperial, por meio do cruzamento de fontes primárias como as atas da Câmara, abaixo-assinados, relatórios médicos e o jornal A Província de São Paulo, renomeado O Estado de São Paulo após o advento da República. A análise da mobilização desse segmento social do abastecimento de gêneros alimentícios compreende as transformações na produção e no comércio de carne, resultantes dos processos de construção de um novo Matadouro Municipal, bem como de proibição do 
abate de porcos em pocilgas particulares, ambos ocorridos no ano de 1886 , em um contexto marcado pela urbanização acelerada e pelo advento da cidade moderna.

Desse modo, abordaremos dimensões da urbanização de São Paulo pouco discutidas pela' historiografia, como também formas de mobilização política na cidade em um período pré-industrial. Apreende-se a influência da economia de abastecimento na configuração do espaço urbano moderno, por meio da análise das relações entre autoridades sanitárias, instituições políticas e segmentos sociais urbanos, em um período de transformações urbanas e socioeconômicas, no qual se destacava progressivamente a influência de noções de higiene e saúde pública na gestão das cidades.

Esteestudo visa contribuir para campos diversos da historiografia. No quese refereàs discussões em história da medicina e da saúde pública, a análise das relações entre o abastecimento de alimentos e o processo de institucionalização da medicina e das políticas de saúde pública em São Paulo revela características desse processo, em um momento anterior à formação do aparato sanitário republicano, que constitui o principal objeto de análise dessa vertente historiográfica. Nesta pesquisa, apreende-se que a configuração de uma política de higiene e sua aplicação no espaço urbano não passaram ao largo das questões da alimentação e do abastecimento de alimentos, desde o início da implementação da política sanitária, com a criação da Junta de Higiene de São Paulo, em 1886, mesmo ano em que ocorre a transferência do Matadouro Público (RIBEIRO, 1993; TELAROLLI JÚNIOR, 1996).

A análise das transformações no abastecimento de carne, no bojo da expansão e modernização da cidade de São Paulo, se baseia, por um lado, no estudo da participação política dos comerciantes de carne, no processo de transferência e afastamento do Matadouro Municipal do núcleo urbano, concluído no ano de 1887; e, por outro, na proibição do abate de animais na cidade fora do estabelecimento público do matadouro.

Estas duas medidas concomitantes visavam ampliar o controle das autoridades urbanas sobrea configuração do abastecimento de carnes, retirando gradativamenteo domínio dos marchantes sobre o processo produtivo, na medida em que outros interesses econômicos e políticos foram sendo incorporados nesse segmento. Todavia, demonstraremos de que modo os marchantes interagiram e influenciaram nesse processo, por intermédio da organização de movimentos coletivos de protesto. Na próxima seção, analisamos a participação dos marchantes de boi no processo decisório de transferência do matadouro. Por fim, investigamos as tentativas da municipalidade de obrigar os marchantes de porcos a realizar sua produção no espaço do 
matadouro. Estes são os dois aspectos constituintes da modernização do abastecimento de carnes na cidade de São Paulo, na última década do regime imperial.

\section{A transferência do Matadouro do Bixiga para a Vila Mariana}

Nesta seção, estudamos o processo de transferência do matadouro, ocorrido no ano de 1886, reconstituindo as transformações na organização do abastecimento de carnes promovidas pela Câmara Municipal e pela ferrovia São Paulo-Santo Amaro. Três aspectos serão analisados para apreender a dimensão política e urbana deste processo: o afastamento do matadouro do núcleo urbano da cidade; a substituição dos marchantes, no processo produtivo, por funcionários públicos municipais; e a incorporação do transporte ferroviário na condução das carnes deste local de produção para a cidade.

Na segunda metade do século XIX, o abastecimento de carnes na cidade de São Paulo esteve submetido à fiscalização e administração municipais. Compilando atas da Câmara e relatos de memorialistas e viajantes sobre a cidade, Bruno (1954) concluiu que, nos períodos colonial e imperial, o comércio desse alimento se caracterizou pela irregularidade e carestia, provocando reclamações da população e a intervenção das autoridades urbanas na produção e comércio realizados pelos marchantes. Como indicativo da importância deste segmento da economia urbana para as relações de poder na cidade, a municipalidade construiu o Curral do Conselho, em fins do século XVIII, com o objetivo de centralizar e supervisionar a produção de carne, especialmente bovina, transferindo-a para um estabelecimento público sob o controle das autoridades.

No decorrer do século XIX, a existência de um local específico para o desempenho dessa atividade produtiva se relacionava também com a preocupação crescente na gestão das cidades quanto à higiene do espaço urbano. Em 1850, a Câmara construiu o primeiro Matadouro Municipal de São Paulo, na Rua Humaitá, bairro do Bixiga, com o propósito de afastar esta indústria do núcleo urbano e organizar a produção, mediante a implementação de novas técnicas de abate, que visavam aprimorar a qualidade da carne.

Desde o início de seu funcionamento, o matadouro suscitou a crítica de autoridades policiais e fiscais da Câmara quanto aos problemas de higiene que continuavam a espreitar o fornecimento de carne. A inadequação do piso para o escoamento dos dejetos, a poluição 
dos rios que atravessavam a cidade, ocasionada pelo esgotamento desse estabelecimento, bem como o domínio dos marchantes sobre o processo produtivo constituíam os principais problemas do Matadouro do Bixiga, segundo a visão das autoridades (CIORDANO, 2006).

Neste contexto, o controle exercido pelos marchantes da produção de carne passou a ser vinculado à ocorrência do fenômeno da carestia dos alimentos e à má qualidade da carne vendida na cidade. Bruno (1954, p. 1109) qualificou o método de trabalho dos marchantes de "cheio de sujeira".

No último quartel do XIX, a expansão urbana e o crescimento demográfico da cidade impuseram novos desafios para a organização do fornecimento de carne, diante do aumento da demanda por gêneros alimentícios. Além dos problemas estruturais do matadouro, 0 loteamento do bairro do Bixiga e as necessidades de ampliar a capacidade produtiva deste estabelecimento selaram o destino do Matadouro da Rua Humaitá, após pouco mais de três décadas de funcionamento.

Em 1887, o estabelecimento foi transferido para as imediações do rio Jabaquara, determinando o processo de urbanização dos bairros da Vila Mariana e Vila Clementino. Nas memórias de Moura (1980) e na obra de Bruno (1954), o significado desta transferência para a história da cidade de São Paulo foi abordado de forma sucinta, justificando-se pela necessidade de afastar o matadouro do núcleo urbano em expansão, bem como de adequá-lo às normas de higiene, no que se referia à organização do processo produtivo.

Os motivos alegados pela historiografia para a transferência do estabelecimento vão ao encontro dos discursos de autoridades e empresários envolvidos no processo, abordando de modo tangencial uma mudança fundamental que visavam instaurar: a expropriação dos marchantes do controle do processo produtivo, deslocando-o para o domínio das autoridades municipais e da ferrovia São Paulo-Santo Amaro. Todavia; o processo político de escolha do novo local do matadouro realizou-se mediante a participação dos marchantes de boi, sendo os interesses desse segmento constantemente mobilizados nos discursos das autoridades para justificar as decisões políticas. Assim, investigamos essa participação dos marchantes, reconstituindo os interesses fundamentais em jogo, os quais se encontravam subjacentes a esses discursos (SILVA, 2018).

A escolha do novo local colocou os marchantes de boi ao lado dos políticos republicanos sediados na Comissão do Matadouro da Câmara, bem como da empresa ferroviária, na articulação de um consenso político para que o novo estabelecimento fosse construído nas imediações da estrada de ferro São Paulo-Santo Amaro. Tal articulação política visava minimizar a resistência que o Partido 
Conservador e o médico da Câmara, Eulálio da Costa Carvalho, impuseram ao projeto, pois tinham o objetivo de transferi-lo para outra região da cidade, o Morro das Perdizes (SILVA, 2018).

A partir da década de 1880 , os republicanos ampliaram sua presença na Câmara Municipal, mostrando-se sua atuação decisiva para a realização dessa transferência e a construção de um novo matadouro na cidade. Diante dos desafios materiais e financeiros que a construção de um novo matadouro colocava ao poder público local, a empresa ferroviária se ofereceu para edificá-lo como parte integrante do projeto da estrada de ferro. Desse modo, o engenheiro Kuhlman se constituiu no principal interlocutor da iniciativa privada, nos debates promovidos pela imprensa.

A transferência desse estabelecimento público suscitou polêmicas e querelas políticas, desde que, no final da década de 1870 , o presidente da Câmara Municipal de São Paulo, o conservador Antônio da Silva Prado, comunicou aos colegas que o terreno adquirido pela municipalidade no Morro das Perdizes deveria servir à construção de um novo matadouro para a cidade. $A$ Câmara autorizou a concorrência pública para a construção de um edifício que comportasse o abate diário de 50 rezes bovinas, 100 ovinas e 100 suínas, em um total de 250 animais abatidos por dia (SÃO PAULO, 1879, p. 33).

A escolha do Morro das Perdizes não era aleatória. Distante do centro da cidade, em uma região de topografia elevada, conforme se julgava mais adequado para esse tipo de indústria, a localidade determinada pelo líder conservador se situava nas proximidades do Curtume de Alberto Kleeberg. Quando, na virada do século, Antônio Bandeira Júnior realizou seu levantamento das principais indústrias da cidade, o estabelecimento de Kleeberg foi considerado um dos mais antigos (BANDEIRA JÚNIOR, 1901, p. 63). Outros interesses econômicos, para além da produção da carne, se confrontavam no processó de transferência, principalmente aqueles ligados às fábricas que utilizavam o couro como sua principal matériaprima. No entanto, esta proposta gerou polêmica na Câmara e eventualmente perdeu força com o fim da hegemonia conservadora em 1882.

Em 15 de março de 1883, os marchantes da cidade se reuniram e apresentaram às autoridades municipais um abaixo-assinado para demonstrar sua preferência em relação ao novo local do matadouro. Tal segmento comercial se mostrava favorável à manutenção desse estabelecimento na mesma região de expansão da cidade, a partir do Bixiga até os "campos realengos da Várzea de Santo Amaro, ou em terrenos do Curtume da Boa Vista, pertencentes a José Antônio Coelho" (SÃO PAULO, 1883, p. 82). As condições de pagamento oferecidas pela empresa ferroviária à Câmara se mostrariam determinantes para a definição do novo 
local, ainda que, nos discursos oficiais e na imprensa, os interesses dos marchantes fossem mobilizados como a principal justificativa para a inclinação das autoridades ao plano da ferrovia.

O engenheiro Kuhlman enfatizava essa confluência de interesses entre a ferrovia e os marchantes, ponderando que a empresa julgava a região da várzea de Santo Amaro como o melhor terreno para a construção do matadouro. Apesar de criticarem a distância entre a cidade e o novo estabelecimento, a proposta da empresa recebeu o apoio dos marchantes, devido às possibilidades de acesso aos locais de pasto nas imediações do novo estabelecimento (KUHLMAN, 1883a, p. 1).

Em 1883, a crítica dos marchantes quanto à distância do local do novo estabelecimento em relação à cidade era compartilhada pelo médico da Câmara, Eulálio da Costa Carvalho. A autoridade sanitária discordou da proposta da empresa, ao posicionar-se de modo favorável à construção no Morro das Perdizes, conforme projetado inicialmente. A região escolhida distava doze quilômetros do núcleo urbano, apartada por uma região de topografia elevada, suscitando dúvidas no médico da Câmara quanto ao impacto na qualidade da carne, quando o produto alcançasse seu destino final, o consumidor.

Tal questionamento se articulava ao debate nas ciências biomédicas entre os paradigmas da bacteriologia e da teoria dos miasmas. Segundo esta perspectiva, estabelecimentos como os matadouros deveriam ser afastados dos núcleos urbanos, por produzirem emanações que contaminavam o ardas cidades, poluíam os rios, constituindo-se na principal causa de doenças: Por sua vez, a ciência bacteriológica propunha que a causalidade das doenças se relacionava à ação de seres microscópicos, transmitidos por vetores como os alimentos (RIBEIRO, 1993).

A ascensão da bacteriologia impugnava a ideia de que o matadouro deveria ser afastado da cidade, segundo a interpretação do médico da Câmara, Eulálio da Costa Carvalho, parajustificar seu posicionamento contrário ao local escolhido pela empresa São Paulo-Santo Amaro. Para esta autoridade sanitária, a higiene do processo produtivo e o fornecimento de água em abundância teriam maior relevância na qualidade da carne e um impacto mais significativo para a saúde pública em comparação com o afastamento do núcleo urbano (CARVALHO, 1883, p. 1-2).

O engenheiro Kuhlman argumentava que os inconvenientes da distância seriam compensados pelo transporte do produto em bondes a vapor, especialmente construídos com a finalidade de ventilar a carne e transportá-la de forma rápida e higiênica aos locais de comércio na cidadé, substituindo o transporte então realizado por carroças pelos marchantes (KUHLMAN, 
1883b, p. 1-2). No entanto, esta modalidade de transporte não seria totalmente suprimida, pois a empresa se comprometia a transportar as peças de carne até a estação denominada São Joaquim, na estrada do Vergueiro. O percurso deste ponto até os açougues da cidade continuaria, portanto, sendo realizado em carroças.

Apesar de compartilharem a crítica em relação à distância do novo local projetado pela empresa ferroviária, a resistência do médico da Câmara suscitou o protesto dos marchantes, em defesa da construção na várzea de Santo Amaro. Por meio de artigo na imprensa, os comerciantes de carne relataram os diversos motivos para o matadouro ser construído nesta região.

O segmento social do abastecimento considerava "natural" a escolha da várzea de Santo Amaro, em função da disponibilidade de pastagens às margens do percurso da estrada de Santo Amaro. Definido pelos conservadores e defendido pelo médico da Câmara, o Morro das Perdizes era reputado como inadequado, pois não possuía espaço suficiente para o descanso do gado nas imediações - diante do processo acelerado de urbanização da região oeste da cidade -, além de se constituir em uma localidade distante de seus respectivos locais de moradia e trabalho.

A representação foi assinada por trinta e um marchantes, em sua maioria possuidores de sobrenomes italianos. A conclusão do documento indicava que, se a Câmara adotasse o parecer do médico, no futuro, as novas condições do abastecimento de carne resultariam em aumento no preço do quilo da carne (REPRESENTAÇÃO, 1883, p. 2).

O engenheiro Kuhlman compôs esta frente de oposição ao parecer do médico da Câmara e aos interesses do Partido Conservador, reforçando a ideia de que a comodidade dos marchantes consistia em elemento crucial para tal decisão, pois a maioria deste segmento do comércio de carne habitava a região entre a estrada de Santo Amaro e a estrada do Vergueiro. 0 argumento da empresa de transportes consistia em estratégia discursiva que se aproximava do posicionamento dos marchantes, possuindo o objetivo de legitimar sua posição e superar as resistências do médico da Câmara e das fileiras conservadoras. Entretanto, subjacente a esta posição, encontrava-se a perspectiva dos lucros a serem auferidos futuramente pela empresa, com a construção do edifício e, principalmente, oriundos da cobrança do transporte da carne do matadouro para a cidade (KUHLMAN, 1883b, p.2-3).

Em abril de 1884, a Câmara decidiu a questão do novo local, favorecendo a posição dos marchantes e da ferrovia, ao indicar que o novo matadouro deveria se situar na região contemplada pela estrada de ferro São Paulo-Santo Amaro. Enfatizava-se, por sua vez, a centralidade dos interesses dos marchantes nesta resolução: 
Considerando que, de parte com o que diz a higiene, a questão mais importante a atender na colocação de um matadouro é a comodidade dos marchantes. Considerando que os marchantes, quase unanimemente, reclamam contra a colocação do novo matadouro nos campos das Perdizes e dos Pinheiros, por falta de pasto e por haver erva nas poucas pastagens existentes. Considerando a importância desta alegação [...] propõe que fique definitivamente escolhido o lugar denominado - rincão do sapateiro. Proporção para o corte de cem rezes, sessenta porcos e cinquenta carneiros, com todo aperfeiçoamento conhecido para esta sorte de construção, não só em relação ao asseio, como também em relação à facilidade da matança, do corte e ao aproveitamento do sebo, e couro (SÃO PAULO, 1884, p. 99.)

A confluência entre a posição política dos marchantes ea proposta da empresa foi determinante para a escolha do novo local pela Câmara. Subjacente à ênfase concedida nos discursos das autoridades e da empresa aos interesses dos marchantes neste processo, a reorganização do abastecimento de carne lhes custaria o domínio sobre o transporte do produto e o aumento nas despesas de sua operação comercial, pois passariam a pagar pelo transporte do matadouro até a cidade. Por sua vez, a determinação do local praticamente favorecia a empresa de Kuhlman na concorrência pública que se seguiu a este debate, pois ela já atuava na região, realizando o transporte ferroviário entre São Paulo e Santo Amaro, mediante contrato público.

Após a determinação do novo local do matadouro, os vereadores lançaram edital para confecção de planta e orçamento da obra para a construção de um edifício com "seus aparelhos", no valor total de 150 contos de réis: A Câmara recebeu, na última sessão do ano de 1884, três propostas de plantas com seus respectivos orçamentos. Entre elas, destacavam-se a do escritório de engenharia de Francisco Ramos de Azevedo e a da Companhia Carris de Ferro São Paulo-Santo Amaro (SÃO PAULO, 1884, p. 203).

Nas primeiras sessões do ano legislativo de 1885 , os vereadores nomearam a Comissão do Matadouro com as seguintes funções: inspecionar o antigo estabelecimento e a construção do novo; estudar as plantas apresentadas na licitação; e fiscalizar as obras. A articulação política para a formação desta comissão levou à composição de uma maioria de políticos republicanos representada por Rafael Paes de Barros e Antônio Paes de Barros (SÃO PAULO, 1885, p. 11).

O engenheiro da Câmara enviou à Comissão do 'Matadouro um parecer sobre as plantas apresentadas em concurso, com direito a prêmio a ser concedido aos dois primeiros colocados. A Comissão do Matadouro anunciou a escolha da proposta do engenheiro Alberto Kuhlman, com Ramos de Azevedo, em segundo lugar (SÃO PAULO, 1885, p. 26). No entanto, na abertura de novo concurso para a execução da obra, a Companhia Carris de Ferro São Paulo-Santo Amaro perdeu a disputa para o escritório de Ramos de Azevedo. Esse resultado inesperado 
da concorrência pública colocava em risco toda a articulação política construída entre ferrovia, marchantes e a Comissão do Matadouro, ameaçando obstruir a transferência do estabelecimento.

Em sessão de 15 de abril de 1885 , a comissão anunciou que o contrato de construção do edifício e de transporte da carne seria concedido à empresa classificada em segundo lugar: a São Paulo-Santo Amaro. Para justificar tal decisão, o líder da comissão argumentou que as condições de pagamento oferecidas pela empresa foram decisivas para esta escolha (SÃOPAULO, 1885, p. 62).

A proposta da empresa versava sobre a duração da obra e as formas de pagamento. O edifício seria entregue até a data de 30 de Setembro de 1886, o que correspondia a um período de 17 meses para a execução da obra. A Câmara, então, teria o prazo de dez anos para concluir o pagamento, a partir de março de 1886 , seis meses antes da data prevista para a conclusão do edifício. Como forma de garantia do pagamento, a Câmara ofereceu os impostos recolhidos sobre os fatos e couros do matadouro e o imposto sobre veículos. O que significava que os marchantes, indiretamente, financiariam a construção do novo estabelecimento.

A proposta de Ramos de Azevedo foi preterida devido à exigência de pagamento imediato em dinheiro. Porsua vez, o engenheiro Kuhlman admitiu que o pagamento fosse realizado "pela forma e com os juros com que o Banco de Crédito Real que foi fundado para projetar a lavoura, [dava] aos lavradores; o que [queria] dizer-de uma forma cômoda para o devedor" (SÃOPAULO, 1885, p. 62).

Desse modo, conclui-se que as condições de pagamento pela obra e a vinculação do abastecimento da carne com o transporte ferroviário foram determinantes para a escolha da empresa e do local do novo matadouro de São Paulo, principalmente devido ao fato de que a municipalidade não possuía recursos para investir nesta obra pública. Tal questão fiscal possuía ainda outra faceta, segundo a comissão: o melhoramento desse estabelecimento não poderia mais ser adiado, pois isto resultava em grande ônus para o Tesouro Municipal, dado o problema estrutural de arrecadação de impostos sobre o abate de porcos.

A comissão entendia que somente com um novo matadouro, mais amplo e moderno, a municipalidade teria instrumentos para colocar fim à prática, costumeira entre marchantes e a população em geral, de abater porcos em pocilgas particulares, prejudicando a cobrança de impostos neste segmento do comércio de carnes e, também, dificultando a fiscalização sanitária da produção e comércio de carne de porco (SÃO PAULO, 1885, p. 63).

Em 30 de setembro de 1885, a engenheiro da ferrovia comunicou à Câmara que as obras de assentamento dos trilhos do ramal do matadouro já estavam concluídas. A Comissão de 
Justiça e Obras incumbiu o engenheiro da Câmara de medir o volume d'água necessário para abastecer o tanque do novo estabelecimento (SÃO PAULO, 1885, p. 143, 171).

Neste ínterim, a oposição conservadora se rearticuloue, pormeio de um de seus representantes,' Aquilino do Amaral, ensaiou uma tentativa de,cancelar o contrato da empresa, argumentando que o local escolhido era "imprestável" e que as águàs disponíveis na localidade eram insuficientes para o fornecimento do matadouro. Para fortalecer sua posição, surgiu na Câmara um abaixo-assinado, organizado por outro grupo de marchantes, criticando a escolha do novo local. Esta última tentativa dos oposicionistas de impugnar o projeto indica que o campo político do Partido Conservador também congregava, além do médico da Câmara, parte do segmento dos marchantes. Todavia, a Comissão do Matadouro indeferiu essa representação e os conservadores foram derrotados (SÃO PAULO, 1885, p. 192).

A transferência do Matadouro do Bixiga para a Vila Mariana visava afastar o local deste estabelecimento do núcleo urbano em expansão, incorporar o transporte ferroviário no abastecimento de carnes, como também instaurar um novo sistema de abate e corte de rezes, comumente referido pelas autoridades da Câmara e pelos historiadores como um sistema moderno e higiênico. A reorganização do processo produtivo tinha como objetivo principal limitar o controle dos marchantes sobre a produção da carne, sobretudo mediante sua substituição na linha de produção por funcionários públicos municipais e incorporação de um sistema integrado de comunicação entre as várias oficinas desse estabelecimento, por meio de tecnologias da empresa ferroviária. Segundo o relato publicado no Correio, logo após a inauguração do Matadouro da Vila Mariana:

Há uma viação interna de trilhos de aço com 39 giradores na extensão de 400 metros. Além destes, tem trilhos suspensos por onde correm ganchos e moitões em roldões para facilitar o serviço. Estes trilhos suspensos comunicam, por uma peçá intercalada, com os trilhos suspensos dos vagões especiais para transporte de carne, de sorte que não há trabalho na carga e descarga. Os vagões são providos de um exaustor duplo, que extrai o ar do vagão expelindo-o por baixo do mesmo vagão, de sorte que a forte corrente de ar estabelecida desde que se põe o vagão em movimento refrigera a carne. (O NOVO, 1886, p. 2)

O processo de transferência do matadouro significava para os marchantes a expropriação de seu domínio sobre a cadeia produtiva da carne, devido à articulação de interesses de grandes empresas nesse segmento, bem como à contratação de funcionários públicos treinados pela Câmara. Desse modo, a municipalidade ampliava o controle institucional sobre esse segmento econômico. Reduzia-se, em contrapartida, o controle dos marchantes sobre o abastecimento 
da carne, que constituía a principal razão para o problema da carestia, segundo as autoridades. Nas palavras do líder da Comissão do Matadouro:

até aqui todo o serviço da matança é feito pelos próprios marchantes que impingem ao público. gato por lebre. No novo matadouro, como em todos os matadouros de cidades importantes, o serviço vai ser feito pela própria câmara, a fim de poder haver vigorosa fiscalização na qualidade do gado. (BARROS, 1887, p. 1-2)

\section{A fiscalização do abastecimento de carne de porco e a resistência coletiva dos marchantes}

No dia 30 de Setembro de 1886, Antônio Carlos de Santa Bárbara, fiscal da Câmara de São Paulo, percorria em diligência o distrito do Brás, quando suspeitou da existência da criação e abate de porcos em uma casa situada na Rua do Pari. Em relatório ao Presidente da Câmara, o responsável pela aplicação da legislação municipal desconfiava que os animais "ali mesmo eram carneados, (porém) hesitou de apresentar-se só, em um lugar distante da cidade e quase que segregado da população para o fim de revistar a existência de porcos e impor a multa" (SANTA BÁRBARA, 1886, p. 25).

As atividades de controle e fiscalização dos produtores e comerciantes de alimentos em São Paulo, nos anos finais do Império e iniciais da República, revelam um cotidiano permeado de tensões entre a municipalidade e os segmentos sociais do abastecimento. No âmbito da profissão de marchante, os comerciantes de porcos constituíam um setor específico sobre o qual, no ano de transferência do matadouro, a Câmara reforçou a aplicação das regras vigentes de produção e comércio de carne, obrigando-os a transferir o processo produtivo, exercido até então em pocilgas particulares, para o Matadouro Municipal. A prática costumeira de abater porcos fora do matadouro foi tolerada pelas legislaturas anteriores da Câmara, a despeito de o Código de Posturas Municipais de 1875 proibi-la. Em 1886, a municipalidade recodificou as Posturas, desencadeando uma política de maior controle e fiscalização sobre a produção e comércio de carne de porco.

O Código de Posturas visava extinguir a criação de porcos no perímetro urbano. Desse modo, proibiu-se que a população criasse os animais, e que fossem mantidos "dentro dos prédios da Cidade e de suas povoações por espaço maior de 24 horas" (SÃO PAULO, 1886b, p. 17). Concomitantemente, definiu-se o matadouro como o único estabelecimento na cidade em que déveria ser realizado o abate de animais para consumo. 
Neste período, os vereadores modificaram a atitude permissiva em relação aos marchantes de porcos e à população em geral, pois crescia a percepção, na Câmara, de que tal situação era prejudicial para a fiscalização sanitária, e também, tributária sobre este segmento da economia de abastecimento. Desse modo, apesar do estágio avançado em que se encontrava o novo matadouro, a municipalidade decidiu ampliar e reformar os espaços no Matadouro do Bixiga, com o propósito de criar as condições necessárias para incorporar o abate de porcos, construindo, assim, uma nova pocilga (SÃO PAULO, 1885, p. 24).

Em fins de 1885, o republicano Manoel Lopes de Oliveira havia proposto a construção de um telheiro provisório na seção de abate de porcos. O plenário acolheu a indicação e o presidente da Câmara ordenou ao engenheiro que "[mandasse] fazer com toda a urgência" (SÃO PAULO, 1885, p. 181). Este investimento, em um estabelecimento que já possuía uma previsão para sua desativação, indicava a urgência que o tema assumiu para o poder municipal, no âmbito da fiscalização das atividades econômicas urbanas. Todavia, o líder republicano na Comissão do Matadouro, Rafael Paes de Barros, questionou a legitimidade da decisão de alocar recursos no antigo matadouro:

Tendo sido deliberado fazer-se no Matadouro um telheiro provisório para a matança de porcos, está se entretanto construindo uma obra de maior dispêndio; e que, como brevemente tem de funcionar o novo matadouro, parece que ficará ali uma obra dispendiosa, sem prestar serviço (SÃOPAULO, 1886a, p. 29.)

A referida comissão visitou o estabelecimento e constatou que a obra da pocilga havia consumido mais de seis contos de réis, o que era considerado uma soma vultosa na época, pois a proposta inicial consistia na realização de obra provisória, de pouco, valor. Todavia, uma vez que já se havia gasto aquele montante, considerou-se mais adequado providenciar mais um conto de réis e, assim, finalizar a obra o mais rápido possível (SÃO PAULO, 1886a, p. 33).

Desse modo, o poder municipal criava as condições para, nos meses seguintes, aplicar a legislação que obrigava os marchantes a realizar o abate de porcos no matadouro, transferindo o processo produtivo, até então pulverizado pela cidade em pocilgas particulares, para concentrá-lo em um único estabelecimento, sob o controle das autoridades municipais.

Neste contexto, os marchantes de porcos se reuniram em assembleia para formular um abaixo-assinado em defesa de seus interesses perante a Câmara. Liderados por Emílio Colia, solicitavam aos vereadores permissão para continuar o abate de porcos em locais de sua preferência. No entanto, em 13 de agosto de 1886, O Correio Paulistano veiculou publicação oficial redigida pelo veterinário do matadouro, comunicando a determinação da Câmara de fiscalizar a produção e o comércio de todos os segmentos da cadeia produtiva da carne: 
Visto achar-se pronto o aumento feito na pocilga junto ao matadouro, avisamos por este que $2^{a}$ feira 16 do mês andante os srs. marchantes deverão fazer a recolhida de porcos [no matadouro] [...] os que não o fizerem sofrerão as penas que a lei determina. (XAVIER, 1886, p. 3)

Em 19 de agosto, ojornal A Província de S. Paulo noticiou que os marchantes de porcos declararam greve para manifestar sua insatisfação com a decisão da. Câmara, principalmente devido às condições de trabalho no matadouro (CREVE, 1886a, p. 2). No dia seguinte, novas informações foram publicadas sobre o movimento coletivo. Segundo a reportagem, os marchantes consideravam que o local construído pela Câmara não contemplava as necessidades impostas pela concentração do trabalho de vários marchantes em um único espaço produtivo:

O local determinado pela Câmara para nele serem abatidos os porcos, só comporta seis pessoas, enquanto que os marchantes são em número de 80 . Não é, pois, um simples descontentamento a causa da greve, porém a completa impossibilidade de no atual matadouro abaterem-se os porcos. Os marchantes já requereram ao presidente da Câmara, mas até o presente nenhuma providência foi tomada [...] esperam que Ihes seja indicado um local apropriado para nele fazerem seu trabalho. (GREVE, 1886b, p. 1).

Segundo esta perspectiva favorável ao movimento dos comerciantes expressa no jornal, a municipalidade subestimara o número de marchantes de porcos na cidade, o que apontava a fragilidade do controle fiscal e sanitário neste segmento. A tentativa da Câmara de reunir em um único local este setor produtivo visava, por um lado, transformar as práticas costumeiras estabelecidas e arraigadas em cada marchante na organização do trabalho, que passaram a ser qualificadas pelas autoridades como anti-higiênicas, indesejáveis em uma cidade moderna, e, por outro, organizar a arrecadação de impostos neste segmento, em função dos processos de urbanização, industrialização e o consequente aumento da demanda por alimentos.

De acordo com o periódico, a Câmara demonstrava pouca disposição para negociar com os grevistas. Os marchantes de porcos, pelo terceiro dia consecutivo, se recusaram a abatê-los no matadouro, alegando que a infraestrutura criada não atendia às necessidades coletivas, intensificando a concorrência comercial no segmento. O movimento decidiu, então, encaminhar outro abaixo-assinado em que propunha, como solução para o impasse, ou a reforma da pocilga ou a continuidade do serviço em pocilgas particulares.

Este segundo abaixo-assinado foi recebido com ceticismo pelo jornal A Província de São Paulo, pois significaria a continuidade da greve, constituindo-se em recusa formal dos marchantes a se sujeitar à decisão da Câmara. Esta, por sua vez, demonstrava "tenacidade em não atender à queixá" do movimento. $\mathrm{O}$ apoio deste veículo à greve refluía e a posição expressa em editorial 
qualificou a paralisação como uma estratégia dos marchantes de burlar a intenção da Câmara de ampliar o controle sanitário sobre a produção e o comércio da carne de porco:

Se [...] não tem razão os marchantes e se recusam levar o gado ao matadouro por não quererem, sujeitar-se a uma reforma do serviço. Enquanto não conhecemos as condições em que se vai fazer a matança, entendemos que não é regular animar os marchantes na resistência à execução da medida legal do poder público que pode ter em seu favor razões de alta valia como são as que aconselham a proibição da matança de porcos sem o exame médico, sem verificação da qualidade da carne que vai ser posta à venda. (CREVE, 1886c, p. 1)

A justificativa apresentada pelo jornal para modificar seu posicionamento se ancorava no argumento da promoção da higiene, evidenciado pela alusão ao controle sanitário dos animais e da qualidade da carne por profissionais médicos. A partir de então, esse veículo da imprensa interveio no conflito, oferecendo-se como mediador nas negociações entre a Câmara e os marchantes.

No quarto dia de paralisação, a redação do jornal convidou os grevistas para comprovarem a veracidade de suas reclamações para os representantes da imprensa e da municipalidade. Em outro editorial, reafirmou que a crítica dos marchantes era legítima devido à impossibilidade de a nova pocilga comportar o volume de rezes abatidas na cidade diariamente, ganhando força a hipótese de que a Câmara desconhecia o número real de porcos consumidos em São Paulo, neste contexto de expansão urbana e crescimento demográfico.

A reduzida capacidade da pocilga em relação ao volume de trabalho a que se destinava estava estreitamente relacionada ao problema fiscal a que sua construção vișava sanar. O engenheiro municipal dimensionou seu tamanho com base na análise dos documentos fiscais da municipalidade. Desse modo, concluiu que o consumo de carne de porco na cidade equivalia ao abate diário de oito animais. Em contrapartida, os grevisțas afirmavam que a quantidade de rezes necessária para o abastecimento diário alcançava oitenta porcos. O jornal A Província, por sua vez, considerava esta cifra exagerada, estimando o consumo médio em 40 porcos:

Pelo cálculo da cobrança do imposto eram abatidos 8 porcos por dia; mas esse não é o número exato e calcula-se em muito mais. Os próprios marchantes dizem ser de 80 atualmente. Dado que haja exageração, ainda aquele número, segundo o pagamento do imposto, não é o real, porque a cobrança era mal feita, sendo apenas regularmente realizada na praça do mercado. Devemos, pois, calcular em muito mais e nunca menos de 40 por dia. (A GREVE, 1886, p. 1)

É possível depreender deste conflito que a municipalidade desconhecia o número real de comerciantes de porcos e de carne de porco na cidade. A construção de uma pocilga no 
antigo Matadouro do Bixiga, na iminência de sua desativação, consiste em um indicativo da centralidade que esta questão assumiu para a municipalidade, nos últimos anos do Império. Em 25 de agosto, quando o segundo abaixo-assinado foi colocado em pauta na Câmara, um dos vereadores da Comissão do Matadouro, o republicano Antônio Paes de Barros, indicou em sua fala a forma como as autoridades municipais pretendiam lidar com o movimento, solicitando a intervenção policial no matadouro:

o fato da relutância feita pelos marchantes de porcos [...] de irem abater os mesmos no matadouro, e bem assim consta-lhe que continuam a fazer em seus chiqueiros, procurando introduzi-los nos açougues às ocultas [...] propõe que se requisite ao Dr. Chefe de Polícia o auxílio preciso para apreensão dos que forem encontrados e que não acompanhar guia de veterinário. (SÃO PAULO, 1886a, p. 179)

Com a aprovação desta proposta, a Câmara amplificava as tensões na cidade, ao solicitar a intervenção do aparato policial. Concomitantemente, questionava a legitimidade do movimento de protesto, ao qualificar suas práticas profissionais costumeiras como formas clandestinas de produção e comércio de carne. A análise dos relatórios de fiscais da Câmara, incumbidos da execução desta ordem, revela que a estratégia traçada pela municipalidade consistia na vigilância das estradas e pontos de entrada de carroças no perímetro urbano. A despeito do recrudescimento do aparato repressivo, os fiscais não flagraram nenhum transporte clandestino de animais ou de carne praticado pelos marchantes no decorrer da segunda quinzena do mês de agosto de 1886 (BRASILIENSE, 1886).

Os comerciantes de porcos e a Câmara estavam em aberto conflito. Os marchantes decidiram recorrer às instâncias de poder superiores, redigindo um terceiro abaixo-assinado endereçado ao governo provincial, demonstrando a capacidade política deste segmento de mobilizar as instituições do regime imperial, com a abertura de espaços de participação social. Entretanto, a resposta do governo provincial se resumiu a indagar o poder local sobre a possibilidade de transferir a produção de carne de porco para o novo matadouro na Vila Mariana, o qual, no entanto, se encontrava ainda em construção.

Concomitantemente, os marchantes solicitaram a vistoria e a elaboração de um parecer sanitário à recém-criada Inspetoria de Higiene de São Paulo, organizada pela Junta Imperial de Higiene, sob a responsabilidade do médico Marcos Arruda. Esta instituição cristalizava a reorganização da política de saúde pública imperial, ampliando o escopo de atuação do governo central nas províncias.

Uma das principais bandeiras do Partido Republicano em São Paulo consistia na defesa de maior autonomia política regional. Nesse contexto, o apelo dos marchantes a um órgão do 
governo central intensificava a disputa em curso com as autoridades locais. O recrudescimento das tensões se materializou no conflito desencadeado entre as autoridades sanitárias da Inspetoria de Higiene de São Paulo, representada pelo médico Marcos Arruda, e o médico da Câmara, Eulálio da Costa Carvalho.

Em 9 de setembro de 1886, a Câmara recebeu o parecer do inspetor de higiene solicitado pelos marchantes. Nesse documento, o médico demonstrava conhecimento das razões da Câmara para refutar as propostas dos marchantes, pois "o atual matadouro funciona só por pouco tempo, visto que por estes seis meses deve estar inaugurado o novo estabelecimento, mas são de tal ordem as condições anti-higiênicas a que se refere, que não poderia deixar de apontálas. (ARRUDA, 1886)“

Com base nessa constatação, Marcos Arruda enumerou os problemas de higiene encontrados na pocilga do Matadouro do Bixiga. Destacava que o calçamento e a cobertura da pocilga alcançavam parte reduzida de seu perímetro, transformando-a em um lamaçal que, além de ser propício às fermentações nocivas à saúde de comerciantes e funcionários, fazia da pocilga um local "inconvenientíssimo" para a produção da carne de porco. Denunciava também que o espaço disponivel era insuficiente para abrigar o trabalho de 80 marchantes, e o fornecimento de água, indispensável para a produção, se caracterizava pela "falta absoluta" deste recurso.

Marcos Arruda observou também que o sistema de suspensão do gado abatido era articulado em polias simples, que obrigavam o emprego de quatro trabalhadores para realizar a ascensão das carcaças, sugerindo que fossem substituídas por polias duplas como um meio de reduzir os riscos de acidentes. Concluía sua exposição afirmando que a demanda dos marchantes era legítima, propondo que, enquanto não fosse transferido o matadouro para a Vila Mariana, a municipalidade deveria permitir aos marchantes continuar a produção em suas pocilgas particulares, justificando tal posição polêmica do seguinte modo:

será mais proveitoso para a saúde pública e mais isento de perigos [...] que se faculte a cada marchante abater o gado miúdo nos antigos lugares costumeiros, porque a matança em lugar certo, determinado e fiscalizado pelas autoridades, como manda a boa higiene, só é exigida para a garantia da salubridade pública, afim de que não sejam abatidos animais doentes mas sendo feita coletivamente a carneação por muitos marchantes, é indispensável que sejam rigorosamente atendidos outros requisitos de higiene, e a insuficiência dos cômodos e a falta absoluta d’água, rodeando o marchante de muitos perigos, pode também ser uma ameaça de peste levantada sobre a população desta capital. (ARRUDA, 1886) 
A posição do inșpetor de higiene incomodou as autoridades municipais. A Câmara não demonstrava disposição para alocar mais recursos em um estabelecimento público com previsão de fechamento, tampouco considerava viável a continuidade dos problemas fiscais e sanitários associados pelos vereadores ao abate em pocilgas particulares. Diante do impasse, o parecer de Marcos Arruda foi enviado para a apreciação do médico da Câmara. Tal procedimento suscitou a crítica mordaz do jornal A Província, que assumia uma posição crítica tanto em relação ao movimento grevista - ao associar os marchantes aos problemas sanitários do abastecimento de carne -, quanto à atitude refratária dos vereadores, no que se refere às demandas desse segmento, legitimadas pelo parecer do inspetor de higiene:

sabem todos que os marchantes representaram à Câmara no sentido de melhorar sua posição que no assunto é precária, tendo pedido antes o parecer do dr. inspetor de higiene, que lhes foi favorável [...] a câmara, nada querendo resolver mandou o ofício do inspetor de higiene ao médico da câmara que, segundo dizem, não morre de amores por aquela autoridade. Assim, em vez de resolver a questão que conforme o parecer daquela autoridade higiênica era tão fácil, usou a câmara de uma escapatória. Continuaremos a ficar ameaçados dos perigos que a péssima matança de porcos e o péssimo local onde é feita pode trazer, enquanto que a câmara ri-se do seu erro em vez de corrigi-lo. (A QUESTÃO, 1886, p. 2)

O médico da Câmara, Eulálio da Costa Carvalho, remeteu no dia 15 de setembro de 1886 sua avaliação do parecer do inspetor de higiene. Eulálio inicia sua resposta enfatizando que, durante a greve dos marchantes, compareceu ao matadouro, em companhia do presidente da Câmara, para avaliar as condições do local e dialogar com os grevistas. Nesta rodada de negociações, estabeleceu-se o compromisso da Câmara de calçar todo o pavimento da pocilga, bem como ampliar a cobertura do telhado.

Após a revelação deste acordo, que não foi cumprido pela Câmara, o médiço aborda as questões específicas apontadas por Marcos Arruda. Adotando uma perspectiva crítica em relação ao posicionamento do inspetor de higiene, evoluindo para uma oposição frontal em sua conclusão, Eulálio da Costa Carvalho inicia sua avaliação pela questão do fornecimento de água para a pocilga. Subjacente a seus argumentos, encontra-se a posição de que Marcos Arruda extrapolava suas funções, ao supostamente interferir em assuntos exclusivos à esfera do poder municipal, ao mesmo tempo em que estaria cometendo prevaricação quanto às prerrogativas legais da função de inspetor de higiene:

O que parece-me digno de reparo é que a autoridade sanitária, observando a falta de águas na seção de matança, não a mencionasse em relação à necessidade do gado bebê-las [...] se aquela falta torna-se muito patente pelas necessidades do serviço, esta deveria ter atraído a 
atenção do higienista, que deve cuidar da saúde dos animais destinados à alimentação pública. (CARVALHO, 1886)

A análise comparada dos pareceres das duas autoridades sanitárias indica uma diferença de perspectiva quanto ao conteúdo dos conceitos de higiene e salubridade pública. No que se refere à produção e comércio de carne de porco no matadouro, o médico da Câmara se baseava na ideia de higiene como uma relação causal e direta entre a qualidade da carne e a saúde do animal, indicando uma visão mais restrita de salubridade, ao minimizar os possíveis efeitos das condições ambientais do matadouro sobre o produto final.

Por sua vez, a posição de Marcos Arruda considerava a intervenção em fatores ambientais e sociais do processo produtivo no matadouro como fundamental para a configuração do controle sanitário da carne, salientando a importância de aspectos como as condições de trabalho a que os marchantes estavam submetidos, o fornecimento de água e a disposição da construção da pocilga, para atingir um ideal de saúde pública nesse segmento do abastecimento de alimentos.

A questão principal da polêmica entre as autoridades sanitárias consistiu na indicação do inspetor de higiene, Marcos Arruda, para que os marchantes continuassem a realizar a produção de carne de porco nas pocilgas particulares, até que o novo estabelecimento fosse inaugurado. Tal proposta lhe rendeu o epíteto de "advogado dos marchantes" no discurso do médico da Câmara, levando esta autoridade a questionar a pertinência de praticamente todas as observações do inspetor quanto à salubridade do Matadouro:

Sem contestar que o atoleiro [...] seja inconveniente, principalmente em relação ao asseio, não posso reconhecer como perigosíssimos seus efeitos sobre a saúde pública ao ponto de julgar menos prejudicial que se ponha a venda carnes de animais abatidos doentes, ou mortos em consequência de moléstias - o carbúnculo, por exemplo, como terá acontecido e poderá acontecer pela inconsciência e avareza de alguns que negociam com tal gênero. O pequeno espaço da matança poderá perturbar a marcha dos trabalhos [...] mas não afetando por forma alguma a saúde dos animais, não poderá prejudicar a salubridade pública. A espécie dos suspensores, já o disse, não poderá ser causa de insalubridade das carnes dos animais abatidos. A falta, ou antes a escassez das águas, poderá ser motivo de menos asseio e maior trabalho, mas não uma causa de insalubridade das carnes [...]. E não considera a autoridade sanitária o estado das pocilgas particulares e os terrenos a elas adjacentes? [...] Muitas, senão todas, são verdadeiros focos de infecção pelo esquecimento do todos os preceitos da Higiene, colocados aqui e ali a cercarem a cidade com suas emanações. (CARVALHO, 1886)

Segundo Mascarenhas (1949); a desavença entre os dois médicos teria se iniciado quando Eulálió foi incumbido da tarefa de assistente de Marcos Arruda na Inspetoria de Higiene de São 
Paulo, em 1884. O movimento de protesto dos marchantes de porcos expôs na cidade as tensões que constituíam o cotidiano das relações entre autoridades e comerciantes no abastecimento de gêneros alimentícios na cidade. Nos conflitos suscitados pela progressiva intervenção das autoridades municipais nesse segmento da economia urbana, o engajamento da Câmara, de comerciantes de carne, da imprensa e de autoridades sanitárias aponta para a relevância da organização do abastecimento de alimentos para os processos de expansão e modernização urbanas, configurando um campo de disputas de interesses econômicos e políticos no qual os marchantes se mobilizaram para viabilizar a continuidade do segmento profissional diante das transformações em curso na cidade.

\section{Considerações finais}

Este estudo sobre o abastecimento de gêneros alimentícios na cidade de São Paulo abórdou as transformações na produção e comércio de carnes na última década do regime imperial, vinculando-as aos processos de expansão e modernização urbanas do fim do século XIX. 0 cruzamento de fontes primárias possibilitou dimensionar os múltiplos interesses econômicos e políticos cristalizados, por um lado, no processo de transferência do Matadouro Municipal do bairro do Bixiga para o da Vila Mariana e, por outro, na proibição do abate de gado no perímetro urbano, concentrando neste estabelecimento público as cadeias produtivas da carne de boi e de porco.

O processo político de escolha do novo local do matadouro desencadeou a articulação de interesses econômicos e políticos de autoridades da Câmara Municipal, da empresa de transporte ferroviário São Paulo-Santo Amaro, dos marchantes de carne e das autoridades sanitárias da cidade. A construção do novo estabelecimento significou a incorporação de grandes capitais no negócio da carne e o início do transporte da carne sobre trilhos, do matadouro até a cidade de São Paulo, substituindo parcialmente o transporte com o uso de carroças realizado pelos marchantes.

A reorganização do abastecimento de carne pela empresa São Paulo-Santo Amaro e pela municipalidade se caracterizou, também, pela implementação de novas tecnologias ferroviárias no processo produtivo, interligando as diversas oficinas do matadouro entre si e com o ramal da estrada de ferro, bem como instituindo um sistema de suspensão das peças de carne has diversas etapas de produção. Enquanto no estabelecimento do Bixiga, os marchantes 
desempenhavam as atividades de abate e preparo da carne, no Matadouro da Vila Mariana, a Câmara Municipal assumia a responsabilidade por essas atividades, mediante a contratação de funcionários públicos. Essas mudanças culminaram na expropriação do domínio dos marchantes sobre o processo produtivo e o transporte da carne.

O processo de transferência do matadouro contemplou outras medidas para reorganizar a cadeia produtiva da carne, entre elas: a proibição do abate de porcos em pocilgas particulares. Em 1875, o Código de Posturas Municipais interditou tal prática, no entanto, esta continuava sendo tolerada pelas autoridades urbanas. Em 1886, desenvolveu-se entre os vereadores a percepção de que esta situação gerava ameaças sanitárias à população e, principalmente, reduzia a arrecadação de tributos vigentes na produção e comércio de carnes, devido às tensões na fiscalização das pocilgas particulares.

Este segmento do comércio da carne resistiu de formas diversas a este processo, deflagrando uma greve que paralisou o fornecimento de carne de porco na cidade por mais de uma semana, em agosto de 1886. Tal conflito se caracterizou pela mobilização de autoridades provinciais e dos profissionais médicos da cidade, notadamente o inspetor de higiene de São Paulo e o médico da Câmara.

Neste contexto, o discurso das autoridades revela a visão negativa e os estigmas sociais vinculados à profissão de marchante, associando este grupo social à existência de perigos sanitários e à carestia da carne que, historicamente, caracterizaram o abastecimento deste gênero alimentício. Assim, a intervenção das autoridades visava reduzir o domínio desse segmento profissional sobre a produção, transporte e comércio de carne, até que fossem eliminados desta cadeia produtiva.

\section{Referências}

A GREVE. A Província de S. Paulo, São Paulo, p. 1, 22 ago. 1886.

A QUESTÃO DO MATADOURO. A Província de S. Paulo, São Paulo, p. 2, 17 set. 1886.

ARRUDA, Marcos. Ofício do Inspetor de Higiene Pública reclamando da demora nos melhoramentos na pocilga recentemente construída: Livro de papéis avulsos 473, Fundo Câmara Municipal, Arquivo Histórico Municípal Washington Luís, São Paulo, 1886. 
BANDEIRA JÚNIOR, Antônio Francisco. A indústria no estado de S. Paulo em 1901. São Paulo: Typographia do Diário Official, 1901. Disponível em: <http://docvirt.com/docreader.net/DocReader.aspx?bib=livross p\&pagfis=23083>. Acesso: 15 set. 2019.

BARROS, Rafael Paes de. A câmara passada. A Província de S. Paulo, São Paulo, p. 1-2, 3 mar. 1887.

BRASILIENSE, Olegário. Livro de assuntos diversos 774. Fundo Câmara Municipal, Arquivo Histórico Municipal Washington Luís, São Paulo, 1886.

BRUNO, Ernani Silva. História e tradições da cidade de São Paulo. Rio de Janeiro: Livraria José Olympio Editora, 1954.

CARVALHO, Eulálio da Costa. Câmara Municipal: Parecer apresentado à mesma pelo respectivo médico o Dr. Eulálio da Costa Carvalho sobre o local do novo matadouro. Correio Paulistano. São Paulo, p. 1-2, 1 dez. 1883.

CARVALHO, Eulálio da Costa. Livro de papéis avulsos 473, Fundo Câmara Municipal, Arquivo Histórico Municipal Washington Luís, São Paulo, 1886.

DIAS, Maria Odila da Silva. Nas fímbrias da escravidão urbana: negras de tabuleiro e de ganho. Revista Estudos Econômicos, São Paulo, v. 15, n. especial, p. 89-109, abr. 1985.

FURTADO, Celso. Formação econômica do Brasil. São Paulo: Companhia das Letras, 2014.

GIORDANO, Carolina. Ações sanitárias na imperial cidade de São Paulo: mercados e matadouros. 2006. 208 f. Dissertação (Mestrado em Arquitetura e Urbanismo)-Pontifícia Universidade Católica de Campinas, Campinas, 2006. Disponível em: <http://www.bibliotecadigital.puc-campinas.edu.br/tde_arquivos/7/ TDE-2007-03-14T074612Z-1283/Publico/Carolina\%20Celestino.pdf>. Acesso em: 19 set. 2019.

GLEZER, Raquel. Chão de terra e outros ensaios sobre São Paulo. São Paulo: Alameda, 2007.

GREVE. A Província de S. Paulo, São Paulo, p. 2, 19 ago. 1886a.

CREVE. A Província de S. Paulo, São Paulo, p. 1, 20 ago. 1886b.

GREVE. A Província de S. Paulo, São Paulo, p. 1, 21 ago. 1886c.

KUHLMAN, Alberto. O novo matadouro. A Província de S. Paulo. São Paulo, p. 1, 25 set. 1883 a.

KUHLMAN, Alberto. O novo matadouro. Correio Paulistano. São Paulo, p. 2-3, 04 dez. 1883b. Disponível em: <http://memoria.bn.br/DocReader/DocReader.aspx?bib=090972_04\&PagFis=4894\&Pesq=\%22no vo\%20matadouro\%22>. Acesso em: 10 dez. 2019.

LENHARO, Alcir. Tropas da moderação: o abastecimento da Corte na formação política do Brasil, 18081842. São Paulo: Símbolo, 1979.

MASCARENHAS, Rodolfo dos Santos. Contribuição para o estudo da administração sanitária estadual em São Paulo. 1949. 575 f. Tese (Livre Docência em Saúde Pública)-Faculdade de Saúde Pública, Universidade de São Paulo, São Paulo, 1949. 
MOURA, Paulo Cursino de. São Paulo de outrora. Belo Horizonte: Itatiaia, 1980.

O NOVO MATADOURO. Correio Paulistano, São Paulo, p. 2, 20 nov. 1886. Disponível em: <http:// memoria.bn.br/DocReader/DocReader.aspx?bib=090972_04\&PagFis=4893\&Pesq=\%22novo\%20 matadouro\%22>. Acesso em 10 dez. 2019.

PETRONE, Maria Thereza. O Barão de Iguape, um empresário da época da Independência. São Paulo: Companhia Editora Nacional, 1976.

REPRESENTAÇÃO. A Província de S. Paulo. São Paulo, p. 2, 30 dez. 1883.

RIBEIRO, Maria Alice Rosa. História Sem Fim... Inventário da Saúde Pública em São Paulo (1880-1930). São Paulo: Editora da Unesp, 1993.

SANTA BÁRBARA, Antônio Carlos de. Livro de papéis avulsos 474, Fundo Câmara Municipal, Arquivo Histórico Municipal Washington Luís, São Paulo, 1886.

SÃO PAULO (Município). Câmara da Cidade de S. Paulo. Atas da Câmara da Cidade de S. Paulo, São Paulo, v. 65, 1879. Disponível em: <http://busca.saopaulo.sp.leg.br/docs/Volumes/at1879v65.pdf>. Acesso em: 15 set. 2019.

SÃO PAULO (Município). Câmara da Cidade de S. Paulo. Atas da Câmara da Cidade de S. Paulo, São Paulo, v. 69, 1883. Disponível em: <http://busca.saopaulo.sp.leg.br/docs/Volumes/at1883v69.pdf>. Acesso em 07 dez. 2019.

SÃO PAULO (Município). Câmara da Cidade de S. Paulo. Atas da Câmara da Cidade de S. Paulo, São Paulo, v. 70, 1884. Disponível em: <http://busca.saopaulo.sp.leg.br/docs/Volumes/at1884v70.pdf>. Acesso em 07 dez. 2019.

SÃO PAULO (Município). Câmara da Cidade de S. Paulo. Atas da Câmara da Cidade de S. Paulo, São Paulo, v. 71, 1885. Disponível em: < http://busca.saopaulo.sp.leg.br/docs/Volumes/at1885v71.pdf>. Acesso em 07 dez. 2019.

SÃO PAULO (Município). Câmara da Cidade de S. Paulo. Atas da Câmara da Cidade de S. Paulo, São Paulo, v. 72, 1886a. Disponível em: <http://busca.saopaulo.sp.leg.br/docs/Volumes/at1886v72.pdf>. Acesso em 07 dez. 2019.

SÃO PAULO (Município). Câmara da Cidade de S. Paulo. Código de posturas do município de São Paulo, São Paulo, out. $1886 \mathrm{~b}$.

SILVA, Leopoldo Fernandes. Entre a praça do mercado e o matadouro: política e abastecimento de gêneros alimentícios em São Paulo nas décadas finais do Império e iniciais da República (1867-1910).2018. $255 f$. Tese (Doutorado em História)-Faculdade de Filosofia, Letras e Ciências Humanas, Universidade de São Paulo, São Paulo, 2018.

SIMONSEN, Roberto. História econồmica do Brasil:1500-1820. Brasília: Senado Federal, Secretaria Especial de Editoração e Publicação, 2005. 
Cidade, Saúde

e Doença

Dossiê

DOI: $10.20396 /$ resgate.v27i2.8656714

TELAROLLI JÚNIOR, Rodolpho. Poder e saúde: as epidemias e os serviços de saúde em São Paulo. São Paulo: Editora da Unesp, 1996.

XAVIER, Antônio Theodoro. Recolhida de porcos, carneiros e cabritos no matadouro. Correio Paulistano, São Paulo, p. 3, 13 ago. 1886.

Recebido em: 25 de setembro de 2019

Aprovado em: 4 de novembro de 2019

152

Resgate-Rev. Interdiscip. Cult., Campinas, v. 27, n. 2 [38], p. 127-152, jul./dez. 2019-e-ISSN: 2178-3284 